\title{
Effect of aluminum content on austenite-ferrite transformation temperature in low carbon (Si-Al) hot rolled GNO electrical steels $\mathbf{(}^{(\cdot)}$
}

\author{
F. Equihua*, A. Salinas* and E. Nava*
}

\begin{abstract}
The aim of the present study is to investigate the synergistic effect of silicon and aluminum content on the austeniteferrite transformation temperatures on cooling ( $\mathrm{Ar} 3, \mathrm{Ar} 1)$ in non-oriented (GNO) Al-Si-low carbon electrical steel strips. Two specimens with different $\mathrm{Al}$ contents: $\mathrm{A}=0.22 \mathrm{wt} \%$ and $\mathrm{B}=0.61 \mathrm{wt} \% \mathrm{Al}$, were analyzed by "in-situ" high temperature $\mathrm{X}$-ray diffraction experiments. The samples were austenitized at $1050^{\circ} \mathrm{C}$ for 5 minutes and sequentially cooling in a stepwise manner by steps of $10^{\circ} \mathrm{C}$ inside an environmental chamber installed in a Philips X'Pert multi-purpose diffractometer. X-ray diffraction patterns were recorded every $10^{\circ} \mathrm{C}$ during cooling from 1000 to $720^{\circ} \mathrm{C}$. The austenite to ferrite transformation temperatures on cooling, $\mathrm{Ar} 3$ and $\mathrm{Ar} 1$, were estimated from changes in the intensities of the (110)- $\alpha$ and (111)- $\gamma$ peaks as a function of temperature. The results of the experiments show that the transformation temperatures increase with increasing aluminum content from 0.22 to $0.61 \mathrm{wt} \%$. In addition, the two-phase field (austenite + ferrite in the system Fe-C decreases with increasing silicon and aluminum contents for these GNO steels. X-Ray diffraction results were supported by microstructural observations of quenched samples of steel $\mathrm{B}$ which were subjected to similar heat treatment conditions than those applied in the X-ray diffractometer experiments. Thin ferrite films $(\sim 4-10 \mu \mathrm{m})$ were observed in the microstructure of specimens of steel $\mathrm{B}$ quenched from temperatures close to the experimental Ar3.
\end{abstract}

\section{Efecto del contenido de aluminio sobre la temperatura de transformación austenita-ferrita en aceros de bajo carbono (Al-Si) eléctricos de grano no-orientado laminados en caliente}

\begin{abstract}
Resumen
El objetivo del presente trabajo es investigar el efecto del contenido de aluminio y silicio sobre la temperatura critica de transformación, durante el enfriamiento, en aceros eléctricos de grano no-orientado (GNO) de bajo carbono laminados en caliente. Dos muestras, con diferentes contenidos de aluminio: $A=0,22$ y $B=0,61 \%$ en peso, fueron analizadas mediante la técnica in-situ de difracción de rayos $\mathrm{X}$ a alta temperatura. Las muestras fueron austenizadas a $1.050^{\circ} \mathrm{C}$ durante $5 \mathrm{~min}$ y, subsecuentemente, enfriadas de manera escalonada cada $-10^{\circ} \mathrm{C}$ dentro de la cámara de alta temperatura instalada en un difractometro Philips X'pert. Los patrones de difracción fueron registrados cada $-10^{\circ} \mathrm{C}$ durante el enfriamiento desde 1.000 hasta $720^{\circ} \mathrm{C}$. La temperatura de transformación austenita - ferrita, Ar3, fue estimada a partir de los cambios en la intensidad de los picos (110)- $\alpha$ y (111)- $\gamma$ en función de la temperatura. Los resultados de dichos experimentos mostraron que la temperatura de transformación, Ar3, aumenta con el incremento del contenido de aluminio, desde 0,22 a 0,61 \% en peso. Adicionalmente, el rango bifásico (austenita + ferrita) en el sistema $\mathrm{Fe}-\mathrm{C}$ disminuye con el incremento de aluminio y silicio en los aceros experimentales. Los resultados de difracción de rayos X fueron sustentados por observaciones microestructurales en muestras del acero B, el cual fue sometido tratamientos térmicos similares a los empleados en los experimentos de DR-X. Se observaron finas capas de ferrita a temperaturas cercanas a la temperatura Ar3 obtenida experimentalmente en el acero B.
\end{abstract}

Palabras clave Acero GNO; Difracción de rayos X in-situ; Transformación austenita ferrita; Acero eléctrico; Capa fina de ferrita.

\section{INTRODUCTION}

Hot rolled grain non-oriented (GNO) electrical steel sheets made of thin-slabs produced by CSP process
(Continuous Strip Processing) were used in this study. The materials employed in the production of this steel include scrap metal $67 \%$ and sponge iron $33 \%$. Big quantities of scrap metal are charged into the

(•) Trabajo recibido el día 16 de julio de 2009 y aceptado en su forma final el día 1 de diciembre de 2009.

* Department of Metallurgy, Cinvestav Saltillo Campus, P. O. Box 663, Saltillo Coah, Mexico 25000. 
electric furnace directly from the container, and therefore, it will result in an increase of residual elements such as $\mathrm{Cu}$ and $\mathrm{S}$. These two elements can cause a strong negative effect on the ductility of the steel during hot rolling process ${ }^{[1]}$.

Actually, two main types of electrical steel: grainoriented and grain non-oriented are manufactured with silicon content from 0.5 to $5 \mathrm{wt} \%$, depending on the use in which they will be applied ${ }^{[2]}$. "Electric" is a term commonly used to describe the application of those steels, which during the service are subjected continually to magnetic fields. By the addition of a small quantity of silicon the magnetic properties of $\mathrm{Fe}-\mathrm{C}$ alloys are much increased.

It is known that alloys steels sheets with silicon for electrical applications in order to reduce power losses which occur with use of alternating current. These losses consist of two components, namely losses resulting from eddy currents and hysteresis losses. Eddy current losses reduce greatly as the content of silicon in the steel increases; hysteresis losses are dependent on impurities in the steel and irregularities in the crystal structure of the steel and increase slightly by alloying with silicon ${ }^{[3]}$. The steels alloyed with Silicon for electrical applications notably improved the performance of the electrical transformers and electric machines. Silicon and Aluminum are the most effective and widely used alloying elements to produce the highest electrical resistivity values of the electrical steels and, therefore, notably diminish the magnetic losses, the induced currents are so difficult to occur and consequently, prevent Foucault currents losses ${ }^{[4]}$.

C-Mn, C-Mn-Al plane and micro-alloyed steels exhibit low ductility tensile test results when the plastic deformation is carried out close to the austenite-to-ferrite transformation temperature Ar3. In general, the curves of area reduction to fracture (RA) as a function of the temperature exhibit a minimum (lost of ductility) that invariably this associated with intergranular cracking ${ }^{[5}$ and 6$]$.

The percent reduction of area at fracture, measured in a tensile test, it is considered as a suitable parameter to determine the ductility of a material ${ }^{[7}$ and 8 . In general, curves of reduction of area at fracture (RA) as a function of temperature exhibit a ductility trough with three regions: A low ductility region and two high ductility regions at highest and lowest temperatures to $\mathrm{Ar} 3^{[2]}$. The results in figure 1 show that the electrical steel manufactured with $100 \%$ sponge iron exhibit a low ductility region (\% RA) < 30) at temperatures between 950 and $1,025^{\circ} \mathrm{C}$, The ductility of the steel is recovered at highest and lowest temperatures. On the other hand, the electrical steel manufactured with $67 \%$ scrap metal, the ductility

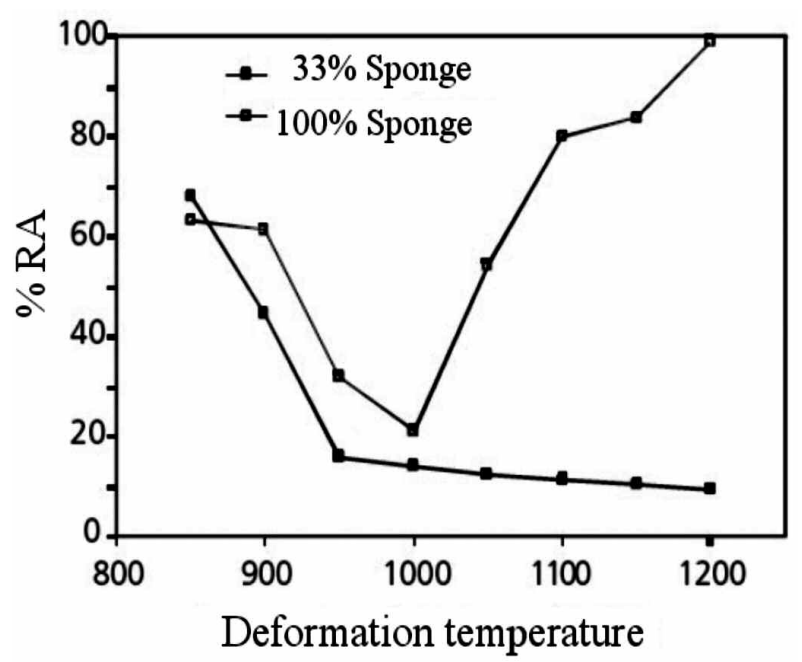

Figure 1. Temperature effect on the ductility of electrical steels austenitized at $1250^{\circ} \mathrm{C}$ for 15 min and deformed at $5 \times 10^{-4} \mathrm{~s}^{-1}$.

Figura 1. Efecto de la temperatura sobre la ductilidad en aceros eléctricos austenizados a $1250^{\circ} \mathrm{C}$ durante $15 \mathrm{~min}$ y deformados a $5 \times 10^{-4}$ $s^{-1}$.

decreases rapidly with increasing temperature from 850 to $950^{\circ} \mathrm{C}$ and $\% \mathrm{RA}<20$ values remain constant until $1,200^{\circ} \mathrm{C}$.

Recent investigations about of the effect of the deformation temperature on the ductility of GNO electrical steels with $0.06 \mathrm{wt} \% \mathrm{C}$, have demonstrated that the minimum of ductility of this kind of steels occurs to temperatures between 1,000 and $1,050 \stackrel{\circ}{ } \mathrm{C}$. In this case, the tensile-crack mechanism changes from transgranular for nucleation, growth and coalescence of microcavities to intergranular. The mechanisms of intergranular cracking of low $\mathrm{C}$ steels deformed at high temperatures have been associated with the formation of intergranular ferrite films (5$20 \mu \mathrm{m}$ thickness) induced by deformation concentrations to temperatures between Ae 3 and $\operatorname{Ar} 3$ on the boundaries of austenite grains ${ }^{[5,6,9}$ and 10]. On the other hand, higher $\mathrm{Ar}_{3}$ temperatures can be obtained by lowering the carbon and Manganese levels or refining the grain size ${ }^{[11]}$. The improvement in ductility at the low temperature end of the hot ductility in steels tested at low strain rates, always corresponds to the presence of a significant volume fraction of ferrite; ferrite having excellent ductility. Thus, straightening at lower temperatures when a significant amount of ferrite is present can give excellent ductility, more than enough to prevent cracking. The presence of ferrite will also ensure that the load requirements for bending are not excessive. 
Two distinctly different microstructural features may lead to strain concentrations at austenite grain boundaries: thin ferrite films and precipitate free zones. Plain carbon as well as low-alloyed steels have been shown to be susceptible to intergranular fracture in the temperature region in which unbending of the continuously cast strand is performed ${ }^{[7]}$.

In order to explain the Phenomenon of Intergranular Cracking during deformation at high temperature of GNO electrical steels, austenite to ferrite transformation temperatures during cooling (Ar3 , Ar1) have been determined using "in situ" high temperature X-ray diffraction technique. The present study has considered two GNO steels with 0.06 wt \% C, 0.61 wt \% Si, $0.5 \%$ wt Mn and two different $\mathrm{Al}$ contents to assess the influence of chemical composition on the transformation temperatures.

\section{EXPERIMENTAL PROCEDURE}

Two $3.5 \mathrm{~mm}$ thick, hot rolled GNO Si-Al low carbon steel strips with aluminiuml contents of $\mathrm{A}=0.22$ and $\mathrm{B}=0.61 \mathrm{wt} \%$ in which the initial microstructure consists of ferrite and pearlite, were the steels used in this work. The specimens were obtained from a production of hot rolled grain non-oriented (GNO) electrical steel sheets made of thin-slabs produced by CSP process (Continuous Strip Processing). The chemical compositions of the investigated steels are shown in table I.

To achieve optimum results using "in situ" $\mathrm{X}$-ray diffraction technique, a sample that is both representatives of the bulk and free of contaminants is imperative. It is required that the specimen thickness be on the order of 0.3 to $0.8 \mathrm{~mm}$. The steps involved in the preparation of this specimen are:

- Reduction of thickness from 3.5 to $0.8 \mathrm{~mm}$. This step involves generating a $0.8 \mathrm{~mm}$ strip using a grinding drill.

- Reduction of thickness from 0.8 to $0.3 \mathrm{~mm}$. The sample is mechanically polished with $\mathrm{SiC}$ abrasive paper on gyratory plate machine. The aim of this process is to thin the center of the steel strip while minimizing damage to the center of the surface of the sample.

- Ultrasonic cleaning. To remove a variety of contaminants from parts immersed in aqueous media (ethanol). The contaminants can be dirt, oil, grease, buffing/polishing compounds.

The dimensions required for the "in situ" experiments were $0.3 \mathrm{~mm}$ thick, $9 \mathrm{~mm}$ wide and 15 mm long.

Each sample was placed on a Platinum filament into the high temperature chamber of the Philips X'Pert diffractometer. In order to obtain the intrinsic results, a moderate flux of Helium gas through the hot chamber leads to, at least ten orders of magnitude, an increment in the X-ray diffraction peak intensities when compared with Argon gas only.

In figure $2 \mathrm{a}$ ) heating and cooling cycles are shown. As can it be appreciated, before to be recorded high temperature X-ray diffraction patterns the humidity of the environment and specimen were dried at $300^{\circ} \mathrm{C}$ for $3 \mathrm{~min}$.

The specimen $\mathrm{A}$ was heated at a rate of $1^{\circ} \mathrm{C} \mathrm{s}^{-1}$ to $300^{\circ} \mathrm{C}$ and soaked during $3 \mathrm{~min}$, then heated at $1{ }^{\circ} \mathrm{C} \mathrm{s}^{-1}$ to $1,050^{\circ} \mathrm{C}$ for $5 \mathrm{~min}$. Subsequently, the temperature was lowered further in a stepwise manner by steps of $1,000,990,980$ down to $720^{\circ} \mathrm{C}$ at a rate of $-1{ }^{\circ} \mathrm{C} \mathrm{s}^{-1}$. At each selected temperature, 2-theta scans between 40 and 45 degrees 2 -theta were measured at $0.02^{\circ} 2$-theta/s to record the diffracted intensities of the $(110)^{\alpha}$ and $(111)^{\gamma}$ peaks in a period of $250 \mathrm{~s}$. Heating and cooling rates between successive temperatures were $\sim-1{ }^{\circ} \mathrm{C} \mathrm{s}^{-1} .28 \mathrm{X}$-ray diffraction patterns for specimen $\mathrm{A}$ were recorded.

The specimen $B$ was subjected to the same heating and cooling conditions to those applied to the specimen A. However, $17 \mathrm{X}$-ray patterns diffraction were measured from 1,000 to $830^{\circ} \mathrm{C}$. No significant shifts in the intensity of peaks below $850^{\circ} \mathrm{C}$ were observed.

To study the influence of the heat treatment and variations in the chemical composition on the resulting microstructure, specimens of steel $B$ were austenitized. In figure $2 \mathrm{~b}$ ) similar conditions to $\mathrm{x}$ ray diffraction measurements during controlled

Table I. Chemical composition of A and B GNO Electrical Steels [wt \%]

Tabla I. Composición química de los aceros eléctricos GNO A y B [\% en peso]

\begin{tabular}{cccccccccccccc}
\hline Specimen & $\mathbf{C}$ & Al & Si & Mn & Mo & S & P & Cu & Cr & V & Ni & Ti & N \\
\hline A & 0.06 & 0.22 & 0.61 & 0.5 & 0.0092 & 0.0005 & 0.00105 & 0.112 & 0.0168 & 0.0004 & 0.046 & 0.001 & 0.0013 \\
B & 0.06 & 0.61 & 0.61 & 0.5 & 0.0095 & 0.0005 & 0.0011 & 0.117 & 0.0164 & 0.00192 & 0.054 & 0.0022 & 0.0015 \\
\hline
\end{tabular}



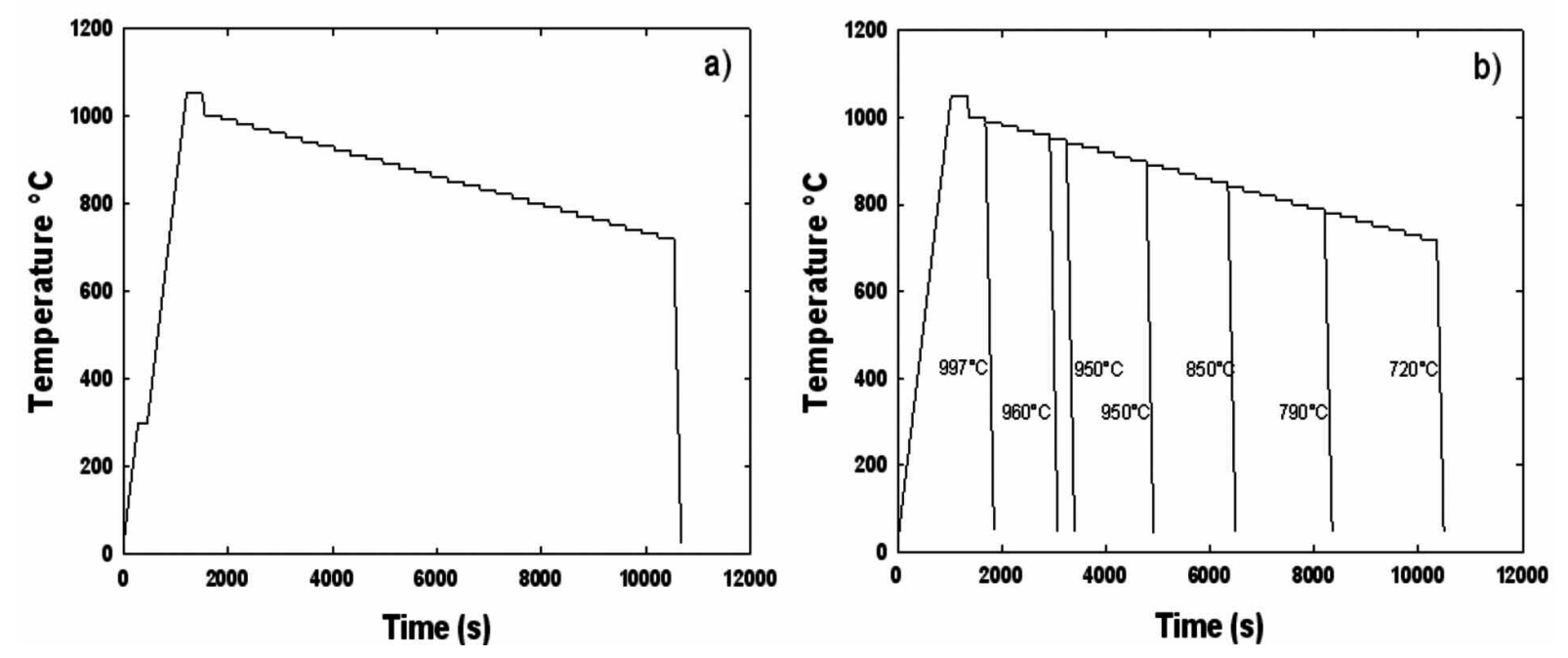

Figure 2. Schematic representation of applied heating and cooling cycles used for a) in-situ X-ray diffraction and b) conventional muffle experiments.

Figura 2. Representación esquemática de los ciclos de calentamiento y enfriamiento usados en a) difracción de rayos $X$ in-situ y b) experimentos en mufla convencional.

thermal cycles of $A$ and $B$ specimens were used in the heat treatments applied to seven $3.5 \mathrm{~mm}$ thick specimens of steel B. All specimens are introduced into a muffle set at $1,050^{\circ} \mathrm{C}$, soaked for $5 \mathrm{~min}$, and then cooled at $1,000^{\circ} \mathrm{C}$. Thereafter, they were directly quenched from selected temperatures: 1,000 , $965,950,900,850,790$ and $720^{\circ} \mathrm{C}$ in a $5^{\circ} \mathrm{C}$ salt icewater bath. The heating and cooling rates applied directly to the specimens during the muffle-heat treatments were $7^{\circ} \mathrm{C} \mathrm{s}^{-1}$ and $0.15^{\circ} \mathrm{C} \mathrm{s}^{-1}$, respectively. The highest quenching rate obtained from these experiments was $-921.4^{\circ} \mathrm{C} \mathrm{s}^{-1}$.

\section{RESULTS AND DISCUSSION}

In figure 3 for a better appreciation the X-ray diffraction peaks are shown from 42 to 45 degrees 2 theta nevertheless, they were measured from 40 to 45 degrees 2-theta. Figure 3 a) illustrates the evolution of X-ray diffraction peaks according to $(110)^{\alpha}$ and $(111)^{\gamma}$ of ferrite and austenite, respectively. As indicated in the figure, the high-intensity peaks of ferrite and austenite appear at 44.6 and $43.4^{\circ} 2 \theta$, respectively. The patterns show changes in the intensities of these peaks, as a function of temperature. It can be appreciated, that austenite is the only equilibrium phase at $1,000^{\circ} \mathrm{C}$. The dotted line shows the $\mathrm{Ar} 3$ temperature obtained in the specimen $\mathrm{A}$, the ferrite phase was not observed during the cooling process from the austenitic rank. The ferrite phase began to appear about $905^{\circ} \mathrm{C}$ and, apparently the austenite-to-ferrite transformation ends at $\sim 730^{\circ} \mathrm{C}$.

The figure $3 \mathrm{~b}$ ) shows the effect of the temperature on the intensity of ferrite and austenite peaks obtained in the X-ray diffraction patterns measured from 40 to 45 degrees 2 -theta during cooling from 1,000 to $830{ }^{\circ} \mathrm{C}$ in the specimen B. At lower temperatures the austenite peak is no longer observed in the diffraction pattern. As can be seen, the ferrite phase appears first at $\sim 940^{\circ} \mathrm{C}$ (pattern marked with dotted line) and, apparently, the transformation ends at $\sim 830^{\circ} \mathrm{C}$. It is also noteworthy that, during cooling from the austenite phase field, the position of maximum intensity of the $(111)^{\gamma}$ peak shifts to larger 2-theta angles as the temperature decreases up to $\sim 830^{\circ} \mathrm{C}$. This effect is due thermal contraction of the austenite. At lower temperatures, this peak shift is no longer observed. This effect is due to the volume changes associated with the phase transformation.

The Ar3 temperature of the specimen B is significantly higher than the observed in low carbon electrical steels; this phenomenon could be attributed to the effect of high contents of silicon and aluminum, which increase the phase stability range of the ferrite in the experimental steels ${ }^{[12}$ and 13].

\section{THERMO CALC SIMULATION}

Figure 4 shows the calculated section of the Fe-Si-CAl phase diagram calculated by Thermo-Calc Software. 

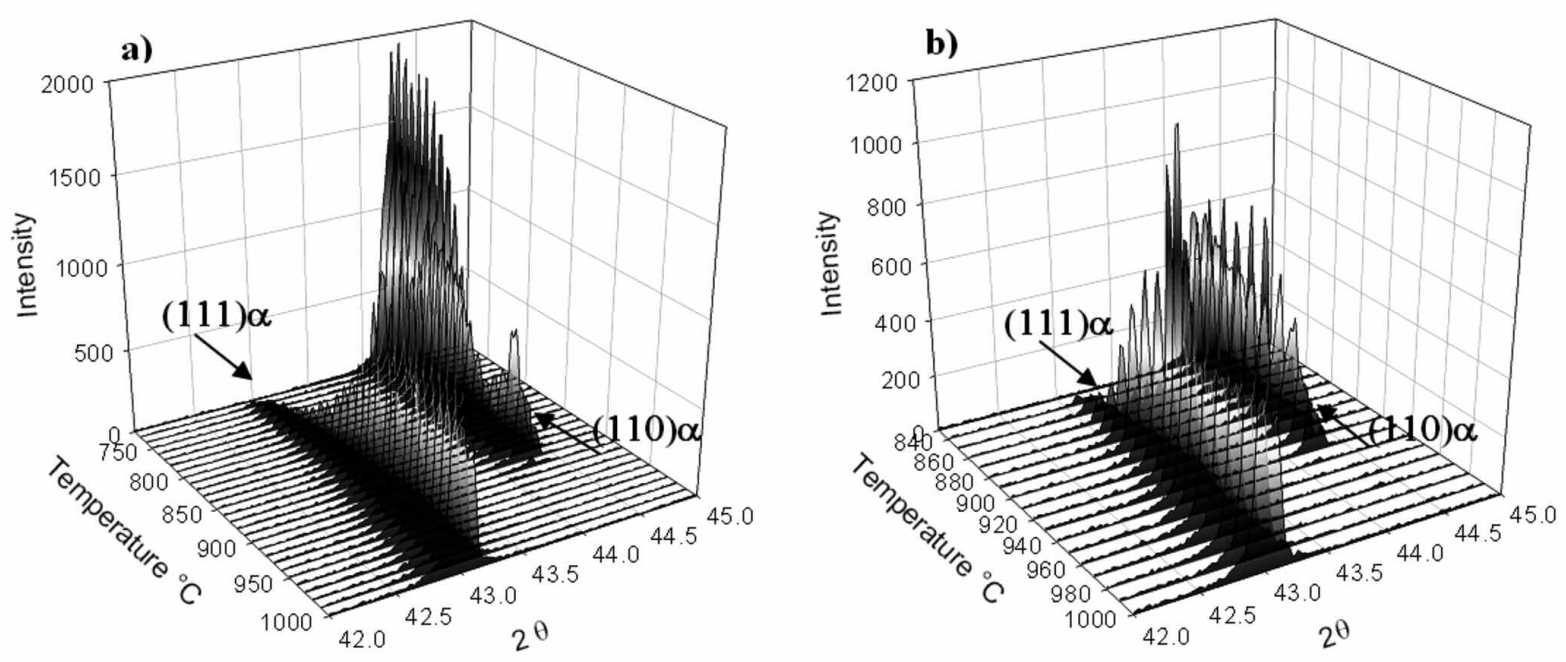

Figure 3. Effect of temperature on the intensity on the X-ray diffraction patterns of low $\mathrm{C}$, GNO Si-Al electrical steel during cooling. a) specimen A from 1000 to $720^{\circ} \mathrm{C}$ and b) specimen $\mathrm{B}$ from 1000 to $830{ }^{\circ} \mathrm{C}$

Figura 3. Efecto de la temperatura sobre la intensidad en los patrones de $D R-X$ de los aceros eléctricos GNO durante el enfriamiento. a) muestra del acero $A$ de 1000 a $720^{\circ} \mathrm{C}$ y b) muestra de acero $B$ de 1000 a $830^{\circ} \mathrm{C}$.

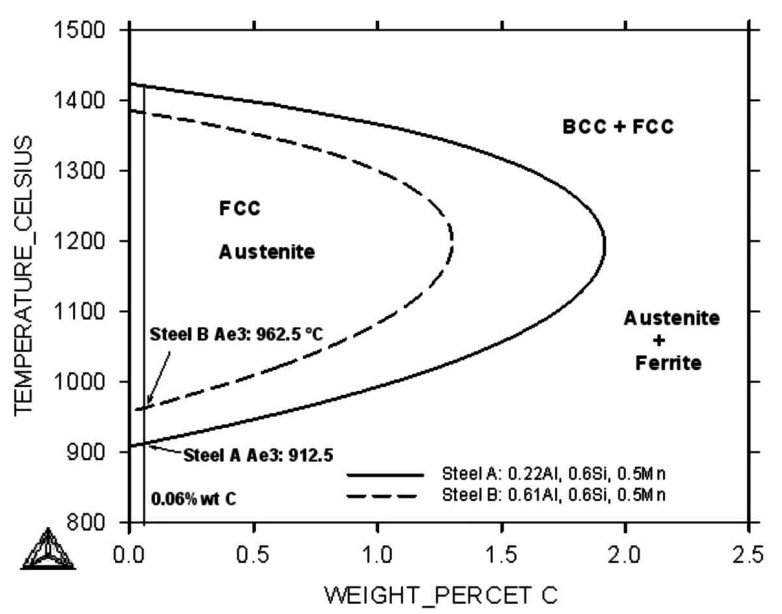

Figure 4. Fe-Si-C-Al phase diagram calculated with Thermo Calc software for chemical composition of specimens $A$ and $B$.

Figura 4. Diagrama de fases Fe-Si-C-Al calculado con Termo Calc para la composición química de los aceros $A$ y $B$.

In this figure, the thermodynamic simulations were carried out by keeping the carbon, silicon and manganese contents constants $(0.06,0.6,0.5 \mathrm{wt} \%$, respectively). The solid line expresses the equilibrium temperature Ae 3 at $912.5^{\circ} \mathrm{C}$ for $\mathrm{Al}$ content of $0.22 \mathrm{wt} \%$ and the dotted one expresses the Ae 3 at $962.5^{\circ} \mathrm{C}$ for $\mathrm{Al}$ content of $0.61 \mathrm{wt} \%$ calculated by Thermo Calc. According to the results obtained in "in situ" X-ray diffraction experiments of $\mathrm{A}$ and $\mathrm{B}$ specimens, the critical transformation temperatures $\mathrm{Ar} 3$ are close to the Ae3 temperatures calculated by Thermo-Calc software.

For $\mathrm{Al}$ content of $0.22 \mathrm{wt} \%$ the calculated critical temperature Ae 3 was determined at $912.5^{\circ} \mathrm{C}$, that is to say, shift to $7.5^{\circ} \mathrm{C}$ lower than the experimental $\mathrm{Ar} 3$ obtained at $905^{\circ} \mathrm{C}$ (specimen A). For $0.61 \mathrm{wt} \% \mathrm{Al}$ the Ar3 simulation was shown at $962.5^{\circ} \mathrm{C}$, that is to say, $22.5^{\circ} \mathrm{C}$ higher than to the $\operatorname{Ar} 3$ obtained on the specimen $B\left(940^{\circ} \mathrm{C}\right)$. In the specimen with the highest aluminium content the two-phase rank $(\gamma+\alpha)$ decreases. Thereby, in the steels with 0.06 wt \% C, alloyed with 0.22 and 0.61 wt \% Al, the two-phase ranks were 175 ${ }^{\circ} \mathrm{C}$ and $110^{\circ} \mathrm{C}$, respectively. Therefore, the contents of $\mathrm{Al}$ and $\mathrm{Si}$ exhibit a synergistic effect on the critical transformation temperatures in GNO-electrical steels.

The effect of the temperature on the magnitude of the integrated intensity (area under the curve) of the $(110)^{\alpha}$ and $(111)^{\gamma}$ peaks obtained in the experiments during the cooling is shown in the figures 5 and 6 . As can be seen, the curves exhibit a sigmoid behavior, characteristic of the diffusion-controlled phase transformation. The main characteristic of this diffusion controlled phase transformation is mass exchange between austenite and ferrite phases leading to spatial extension of ferrite phase while the austenite phase shrinks. 

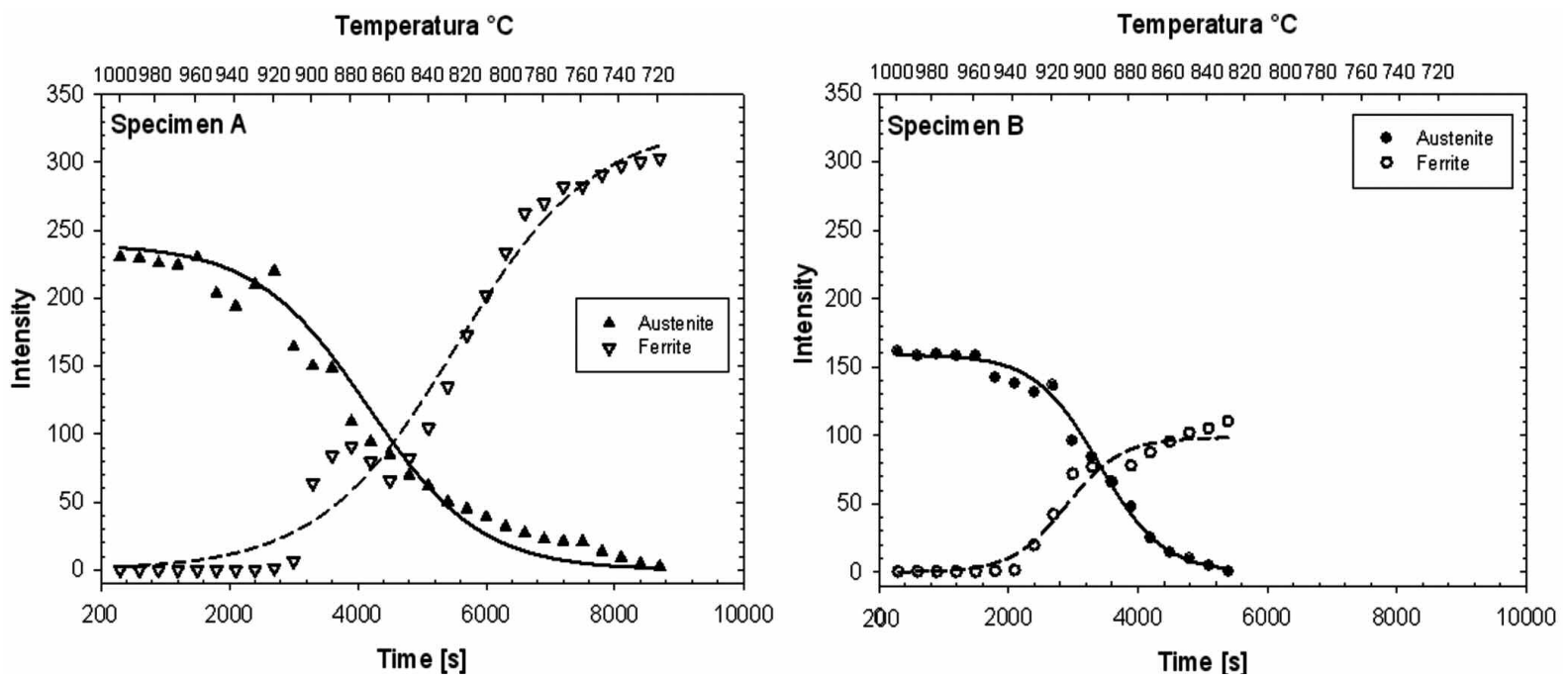

Figure 5. Kinetics of austenite-ferrite transformation for samples A and B.

Figura 5. Cinética de transformación austenita-ferrita para los aceros $A$ y $B$.
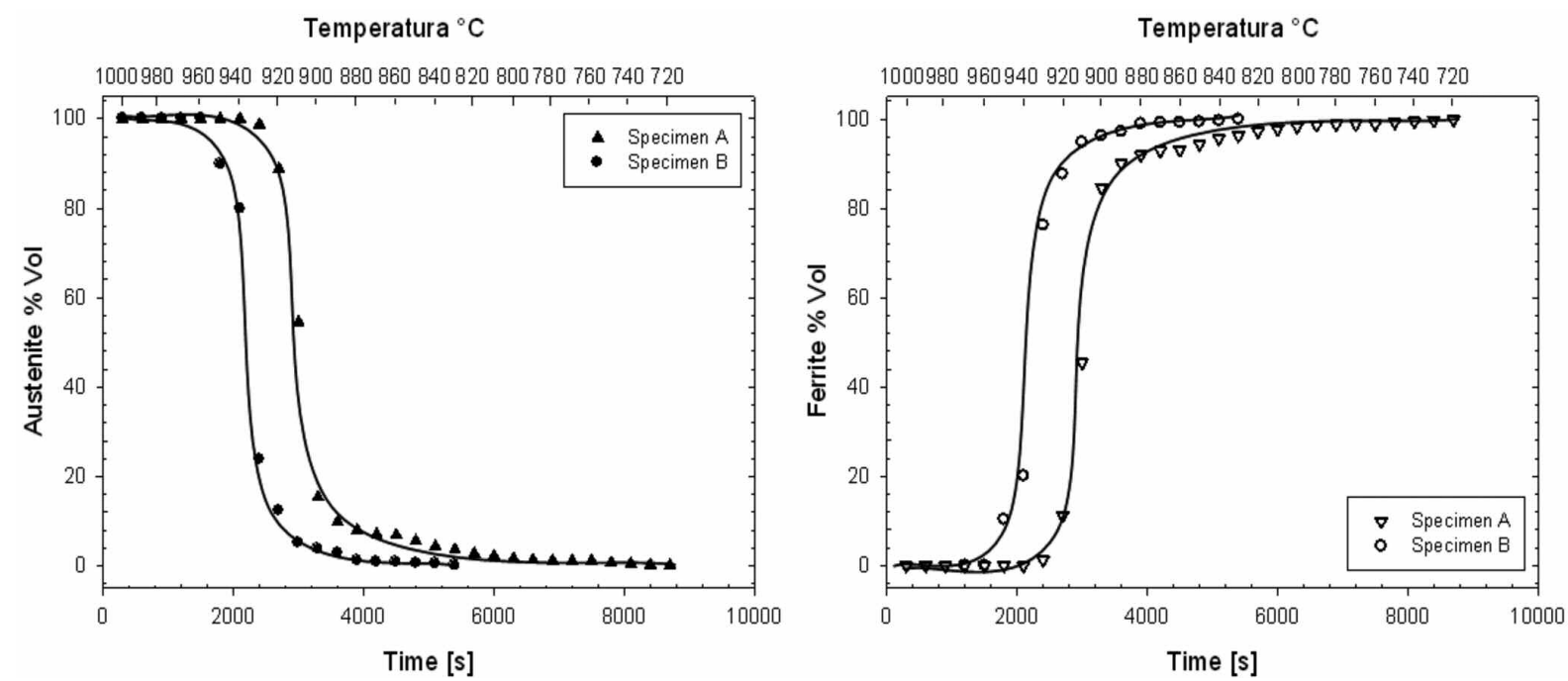

Figure 6. Effect of aluminium content volumen of austenite and ferrite of experimental specimens.

Figura 6. Efecto del contenido de aluminio sobre el porcentaje en volumen de las fases austenita y ferrita.

The integrated intensity of the diffraction peaks is proportional to the volume fraction of ferrite or austenite, that is produced whereas the X-ray diffraction pattern is recorded, added to the volume fraction of these phases contained in the steel before the temperature increase or decrease. Thus, these curves are an indicative mode of the additional quantity of phase (austenite or ferrite) that can be formed when the temperature decrease. In any event, the curves can be used to estimate the coexistence of ferrite-austenite rank in the steel. Figure 6 shows the volume percentage of ferrite and austenite of the specimens A and B, it can also be appreciated that, the high content of $\mathrm{Al}$ accelerates the kinetics of the austenite-ferrite transformation.

\section{HEAT TREATMENT}

Figure 7 illustrates the evolution sequence of the microstructure in specimens of steel B quenched into a salt ice-water bath at $5^{\circ} \mathrm{C}$. It can be appreciated, after quenching from $997^{\circ} \mathrm{C}$, at room temperature the microstructure consists of a martensitic 


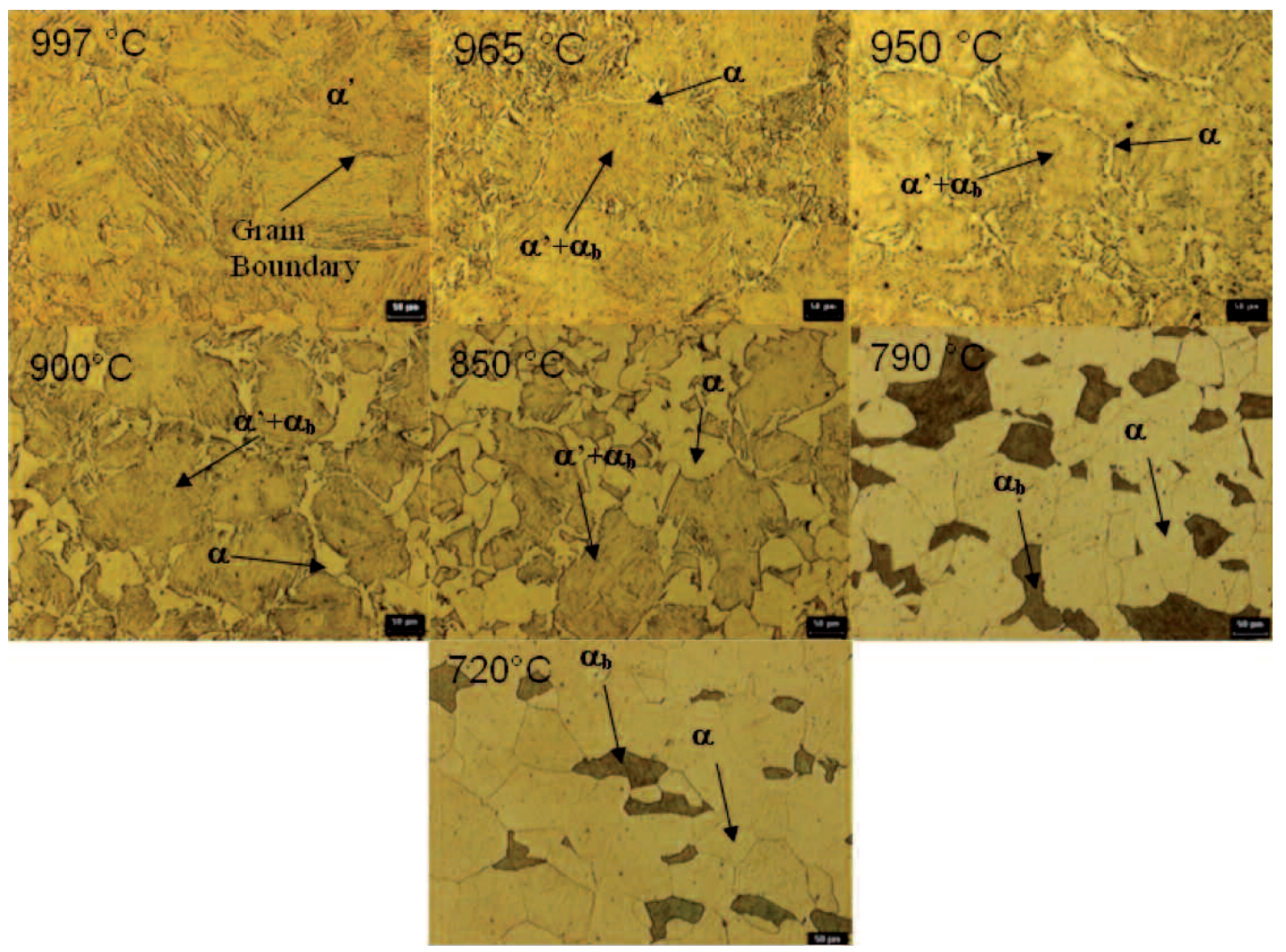

Figure 7. Effect of temperature on microstructure of specimen of steel B austenitized and quenched. Martensite $\left(\alpha^{\prime}\right)$, Bainite $\left(\alpha_{b}\right)$ and Ferrite $(\alpha)$.

Figura 7. Efecto de la temperatura sobre la microestructura de muestras del acero $B$ austenizadas y templadas. Martensita $\left(\alpha^{\prime}\right)$, Bainita $\left(\alpha_{b}\right)$ y Ferrita $(\alpha)$.

microstructure. However, in the specimen rapidly quenched from 965 , the microstructure shows thin films of ferrite of $\sim 4.5 \mu \mathrm{m}$. At $950^{\circ} \mathrm{C}$ ferrite phase thickens to $8.3 \mu \mathrm{m}$. At temperatures below $950^{\circ} \mathrm{C}$, the ferrite films thicken following a parabolic behavior according to ${ }^{[14]}$. Figure 8 shows the effect of temperature on thickens of ferrite phase. Can be appreciated that the concentration of the deformations at a ferrite layer formed surrounding the austenite grains at temperatures corresponds to Ae 3 and Ar3 rank according to ${ }^{[6}$ and 7$]$. It is evident that the austenite-ferrite transformation is a diffusional process of carbon, and the distribution of carbon atoms between ferrite and austenite and also, carbon diffusion in non-transformed austenite are the process to determine phase transformation rate. Nucleation and growth of ferrite phase at the boundaries of austenite occurs during cooling of austenite phase, this ferrite is known as pro-eutectiod ferrite. Growth of ferrite follows a parabolic law as a function of time. This kinetic behavior is due to carbon accumulated, just at the interface of austenite phase, increases; therefore, most time will be required to diffusion of carbon to the middle of nontransformed austenitic grain. The diffusion process of carbon atoms at the volume of austenite determines the growth of ferrite.

The microstructure of specimens quenched from 950 to $850^{\circ} \mathrm{C}$ consists of a mixture of three phases: ferrite $(\alpha)$, martensite $\left(\alpha^{\prime}\right)$ and bainite $\left(\alpha_{\mathrm{b}}\right)$. In this case, quenching causes formation of bainite islands $\left(\alpha_{b}\right)$ in a ferritic matrix. The transformation of residual austenite during quenching produces the bainitic morphology. The thick of the ferrite progressively increases with diminishing heat treatment temperature (Fig. 8) and, therefore, the quantity of bainite obtained during the quenching diminishes as can be appreciated in figure 7 .

\section{CONCLUSIONS}

Austenite-ferrite critical transformation temperatures for low carbon $\mathrm{Si}$-Al hot rolled GNO steels were determined by "in situ" X-ray diffraction technique. 


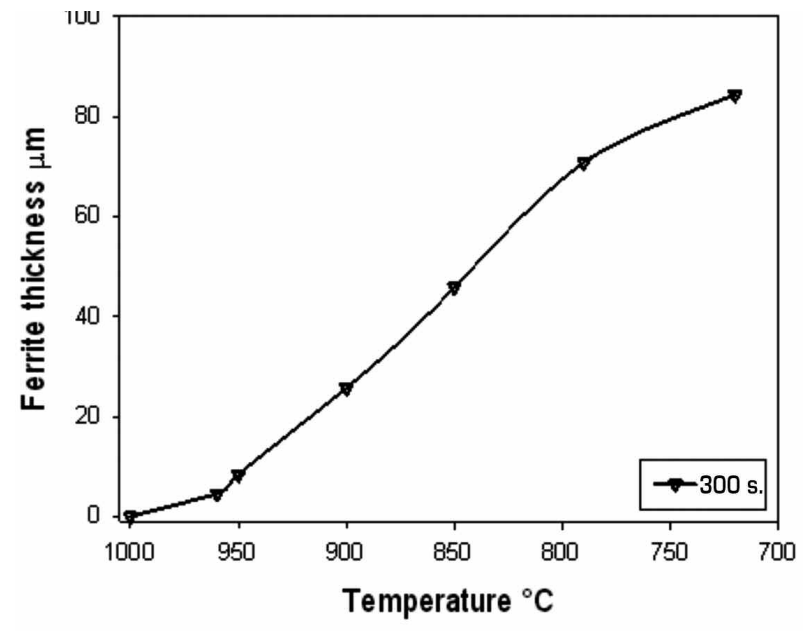

Figure 8. Effect of temperature on the thickness of ferrite in specimens of steel B austenitized and quenched.

Figura 8. Efecto de la temperatura sobre el espesor de la ferrita en muestras del acero $B$ austenizadas y templadas.

For the steel with 0.22 wt \% Al, the Ar3 and Ar1 temperatures were found to be 905 and $730{ }^{\circ} \mathrm{C}$, respectively.

Austenite-ferrite transformation in GNO steels depends on the $\mathrm{Al}$ and $\mathrm{Si}$ contents, increasing $\mathrm{Al}$ to 0.61 wt \% causes $\mathrm{Ar} 3$ to increase to $940^{\circ} \mathrm{C}$ and $\mathrm{Ar} 1$ to $830^{\circ} \mathrm{C}$. Increasing the aluminium content in this kind of steel reduces considerably the austenite-ferrite phase field. Aluminium and silicon produce a synergistic effect; the aluminum has not a strong effect as the silicon on the critical transformation temperatures ( $\mathrm{Ar} 3$ and $\mathrm{Ar} 1$ ) of Si-Al GNO electrical steels. In addition, increasing aluminiuml content accelerates the kinetics of austenite-ferrite transformation.

Thermo Calc simulations show Ae 3 temperatures close to Ar3 temperatures of the experimental steels due to DRX experiments were not made under continuous cooling conditions completely. However, the Ar3 temperature obtained by DRX in-situ technique can be consider as the most critical temperature in which the ductility loss occurs during hot rolling process of GNO steels.

Thin ferrite films (4-9 $\mu \mathrm{m}$ thick) were observed on the microstructures of steel $B$ specimens quenched from a temperature close to Ar3. The thickness of the ferrite films formed surrounding the austenite grains does not change significantly with temperature at temperatures between $\mathrm{Ae} 3$ and $\mathrm{Ar} 3$. At temperatures below $\mathrm{Ar} 3$ the ferrite film thickens rapidly and, in this point, the ductility will be fully recovered when approximately $40 \%$ ferrite is present
( $~ 25 \mu \mathrm{m}$ thick ferrite). Finally, the present study contributes to reduce the incidence of intergranular cracking in Al-Si hot rolled GNO electrical steels.

\section{Acknowledgements}

The authors are grateful to Consejo Nacional de Ciencia y Tecnología (CONACYT) for financial support, Ternum-Hylsa for the provision of the GNO steels, Galvak (Antonio Chaveznava) and U Saltillo Cinvestav (Sergio Rodriguez) for the provision of laboratory facilities.

\section{REFERENCES}

[1] E.O. García-Sánchez, E.A. Treviño-Luna, A. Salinas-Rodríguez and L.A. Leduc-Lezama. Rev. Metal. Madrid 43 (2006) 266-271.

[2] Silicon-Steel Electrical Sheets, pp. 1157-1162. Carbon Steels, Ninth Edition, pp.1117-1128.

[3] Den Hartog, Huibert W. (Noordwijkerhout, $\mathrm{Nl}$ ) Van Haastrecht, Gijsbertus C. (Heemskerk, Nl). United States Patent 5262039.

[4] European Copper Institute (Eci), FraunhoferISI, KU Leuven and University of Coimbra, Energy Efficient Motor Driven Systems, 2004.

[5] B. Mintz, S.Yue and J.J. Jonas. Int. Mater. Rev. 36 (1991) 187.

[6] J.Y. Fu, I. García, S. Pytel and A.J. de Ardo. Proc. Microstructure and Properties of HSLA Steels, 27. 1988. Warrendale, PA, U.S.A., Metallurgical Society of AIME.

[7] B. Mintz, S. Yue and J.J. Jonas, Int. Mater. Rev. 36 (1991) 187-217.

[8] J. Lewis, J. J. Jonas and B. Mintz, ISIJ Int. 38 (1998) 300-308.

[9] A. Cowley, R. Abushosha and B. Mintz, Mater. Sci. Technol. 14 (1998), 1145-1153.

[10] B. Mintz, R. Abushosha and M. Shaker, Mater. Sci. Technol. 9 (1993) 907-914.

[11] B. Mintz, Importance of $\mathrm{Ar}_{3}$ temperature in controlling ductility and width of hot ductility trough in steels, and its relationship to transverse cracking. Department of Mechanical Engineering and Aeronautics, City University, London, vol. 12, no 2, 1996, pp. 132-138 (19 ref.).

[12] J.H. Oh, S-H. Cho and J.J. Jonas, ISIJ Int. 41 (2001) 484-491.

[13] B. Mintz, A. Tuling and A. Delgado, Mater. Sci. Technol. 19 (2003) 1721-1726.

[14] R.C Reed and H.K.D.H Bhadeshia, Mater. Sci. Technol. 8 (1992) 421-435. 